\title{
Elefánt a porcelánboltban? Az Amerikai Egyesült Államok Latin-Amerika-politikája Donald Trump elnöksége alatt
}

\begin{abstract}
Latin-Amerika, bár évtizedekig kiemelt helyet foglalt el az Amerikai Egyesült Államok külpolitikájában, a hidegháborút követö időszak egyéb világpolitikai eseményei egyre hátrébb sorolták a régiót Washington prioritásai között. Mindez azonban a 2016-os választási kampányban megváltozni látszott, mikor Donald Trump több Latin-Amerikát érintő kérdést is kampánytémává tett. A tanulmány azt vizsgálja, hogy történtek-e valós változások az Egyesült Államok, valamint a latin-amerikai és Karibi-térség államai közti viszonyban, illetve hogy milyen hangsúlyok jelentek meg ebben a megközelitésben, valamint milyen eltérések figyelhetők meg az elnök és a kongresszus relációjában.
\end{abstract}

Kulcsszavak: Latin-Amerika, Donald Trump, Egyesült Államok, Venezuela, Mexikó, Kuba, migráció

Vogel Dávid: The Latin America Policy of the U.S. Under Donald Trump's Presidency

Even though Latin America had occupied a prioritised position in the foreign policy of the U.S. for decades, world politics after the Cold War resulted in a dwindling importance of the region for Washington. This trend seemed to change during the 2016 presidential election campaign as Donald Trump made several Latin America related issues campaign topics. The current study examines whether there had been substantial changes in U.S. - Latin American and Caribbean relations and what issues had been emphasized in this regard. The differing positions of the U.S. president and the Congress will also be analysed.

Keywords: Latin America, Donald Trump, United States, Venezuela, Mexico, Cuba, migration

\section{Bevezető helyett}

Az Amerikai Egyesült Államok (a továbbiakban: Egyesült Államok) latin-amerikai és karibi ${ }^{1}$ érdekeinek alakulását elsősorban négy tényező határozza meg: a gazdasági, a politikai, a biztonsági és a humanitárius kérdések. Ezek sorrendje és az egyes elemek súlya azonban időről időre változik annak érdekében, hogy a mindenkori washingtoni vezetés szája íze szerint alakuljon az „Egyesült Államok hátsó udvara”. A hidegháború évtizedei alatt

\footnotetext{
A tanulmányban az egyszerűség kedvéért Latin-Amerika, illetve LAC/LAC-régió kifejezés alatt értem az Amerikai Államok Szervezetének valamennyi tagállamát az Egyesült Államokat és Kanadát leszámítva.
} 
megszokott volt, hogy Washington baráti rezsimek támogatásával biztosította befolyását Latin-Amerikában, a bipoláris világ átalakulásával azonban a kapcsolatrendszer is átalakult és gazdasági síkra terelődött: az Egyesült Államok elsősorban szabadkereskedelmi megállapodások megkötésével próbálta biztosítani regionális pozícióját. Mindazonáltal a baráti kormányok támogatása természetesen nem került le teljesen a napirendről, de jelentős átalakuláson ment keresztül mind volumenében, mind minőségében. Az évek során a hangsúly a kábítószerellenes küzdelemre, az ahhoz kapcsolódó nemzetközi szervezett bűnözés felszámolására, valamint a sokszor e két jelenség miatt generálódó migráció kezelésére tevődött át. Donald Trump politikai színtérre kerülésével, azaz a 2016-os kampánnyal, újra elötérbe kerültek ezek a korábban már szabályozott területek: fal építése (mexikói büdzséből) az Egyesült Államok déli határára a Mexikó felöl érkező bevándorlók megállítására, a menekültstátusz, valamint az ahhoz kapcsolódó mechanizmusok felülvizsgálata, a szabadkereskedelmi megállapodások átfogó reformja (a NAFTA átalakítása, Trans-Pacific Partnership megvétózása), az Obama-adminisztráció kubai kapcsolatokat érintő intézkedéseinek felfüggesztése és/vagy leépítése. A kampányígéreteket természetesen saját egyedi környezetükben kell értelmeznünk, így azok sokszor mindössze a politikai agenda tematizálásának vagy a szavazatmaximalizálásnak az eszközei, és nem jelentenek valódi politikai szándékot. Trump esetében azonban elmondható, hogy ha nem is sikerült valamennyi Latin-Amerikát érintő kampányígéretét megvalósítani, azok érdekében történtek lépések. Az amerikai politikai rendszer sajátosságainak köszönhetően a külpolitikai döntések azonban nem kizárólag az elnök elképzeléseitől és akaratától függenek, így a Kongresszus döntéseinek is jelentős szerep jut.

A 2017 januárjától felálló Trump-adminisztráció előtt tehát számos kitűzött cél ismert volt már, ezek azonban nem álltak össze egységes Latin-Amerika-politikává. Erre valamivel több mint egy évvel később, 2018 februárjában került sor, mikor Trump első külügyminisztere, Rex Tillerson nyilvánosan is ismertette a kormány 2018-2022-re vonatkozó stratégiai tervét, amelyből - bár az nem régiók szerint, hanem kijelölt célok, illetve azokon belül megfogalmazott egyes stratégiai célkitüzések mentén ismerteti a távlati terveket - kivehetö egyfajta Latin-Amerika-politika is. A stratégia az amerikai érdekek három pilléreként a gazdasági növekedést és prosperitást, a biztonságot, valamint a demokratikus kormányzást jelölte meg. ${ }^{2} \mathrm{Ez}$ az irányvonal azonban nem hozott szignifikáns változást az Obama-adminisztráció Latin-Amerika-politikájához képest, sőt, ha megnézzük a 2015ben bevezetett, kifejezetten Közép-Amerikára vonatkozó irányelveket, akkor szinte szóról szóra megegyező tartalmat fogunk találni. ${ }^{3}$

\section{Washington és a regionalizmus}

Az Egyesült Államok második világháborút követő történelme során számos alkalommal használta az Amerikai Államok Szervezete (Organisation of American States - OAS) által nyújtott teret és mechanizmusokat regionális politikai elképzeléseinek kivitelezéséhez.

\footnotetext{
Joint Strategic Plan FY 2018-2022, [online], 2018. 02. Forrás: U.S. Department of State [2020. 01. 28.]

Latin America and the Caribbean: Issues in the $115^{\text {th }}$ Congress, [online], 2019. 01. 22. Forrás: Federation of American Scientists [2020. 01.22.]
} 
Az OAS-t azonban a „pink tide” (azaz rózsaszín dagály) 4 időszakának baloldali latin-amerikai kormányai által életre hívott egyéb szervezetek (ALBA, UNASUR, CELAC) ${ }^{5}$, valamint az általános Washington-ellenes hangulat (összekapcsolódva az OAS hidegháborús szerepvállalásának emlékével) egyre inkább háttérbe szorította. Az Obama-kormányzat részben új megközelítése - amely leginkább csak retorikájában tért el a korábbi republikánus időszaktól - valamelyest próbálta orvosolni ezt a helyzetet, így többek között 47 év felfüggesztett státuszt követően Kuba is lehetőséget kapott a szervezetbe való visszatérésre, még ha ezzel a lehetőséggel Havanna nem is élt. A folyamatos konzultáció mellett az OAS legmagasabb szintü tanácskozása, az 1994 óta 3-4 évente megrendezésre kerülő Összamerikai Csúcstalálkozó (Summit of the Americas) mindig kiváló alkalmat szolgáltat az aktuális washingtoni elképzelések ismertetésére, valamint szövetségesek keresésére. A regionális szinten kiemelt jelentőséggel bíró találkozót egyetlen alkalommal rendezték meg az épp hivatalban lévő amerikai elnök jelenléte nélkül: Trump a 2018-as limai csúcsra alelnökét, Mike Pence-t küldte. ${ }^{6}$ A 2018. április 13-14-én megrendezett csúcstalálkozó lett volna egyébként Trump első latin-amerikai útja, amelyre végül az év végén, november 30-a és december 1-je között került sor a Buenos Aires-i G20-csúcs alkalmával. ${ }^{7}$ Az argentin út egyben az egyetlen elnöki utazás Latin-Amerikába, annak ellenére, hogy számos szövetséges is található a régióban. Összehasonlításképpen: elődje, Obama első három évében négy országban (Mexikó, Brazília, Chile, El Salvador) tett látogatást, Mexikóban két ízben is, és még a régióban Trumphoz hasonlóan szintén nem túl népszerü George W. Bush is három államot (Peru, El Salvador. Mexikó,) keresett fel, utóbbit három alkalommal. ${ }^{8}$ Megjegyzendő azonban, hogy az elnök távollétét ellensúlyozandó, a nyilvánosan hozzáférhető információk alapján Mike Pence alelnök öt, a külügyminiszterek (Rex Tillerson, illetve Mike Pompeo) hat, illetve 14 alkalommal jártak a régióban 2019 végéig. ${ }^{9}$

Tekintettel arra, hogy az amerikai külpolitika már korábban belátta, hogy a regionális befolyás erősítése érdekében létrehozni szándékozott Amerikai Szabadkereskedelmi Övezet (Free Trade Area of the Americas - FTAA) nem realizálható, Washington kevesebb partnerország egyszeri bevonásában látta a megoldást kereskedelmi (és részben politikai) elképzeléseinek megvalósítására. Ennek értelmében jelenleg 20 országgal van érvényben szabadkereskedelmi megállapodása az Egyesült Államoknak, amelynek több mint fele, 11 a latin-amerikai térségben köttetett. Ezeket két multilaterális szerződés - Mexikó

4 „Pink tide” alatt a Latin-Amerikában az ezredfordulót követően beállt baloldali politikai fordulatot értem, amelyek során baloldali kormányok kerültek hatalomra Dél-Amerika államainak döntő többségében, valamint számos más LACtérségbeli országban. A kivétel Venezuela, ahol a pink tide időszakát Hugo Chávez 1998-as megválasztásától számítjuk. A tanulmányban a kifejezés angol változatát használom, tekintettel arra, hogy sem a tükörfordításként felmerülő rózsaszín ár/áradat (spanyolul: marea rosa), sem a portugálban használt rózsaszín hullám (onda rosa) nem honosodott meg.

5 ALBA: Bolivári Szövetség a Mi Amerikánk Népei Számára (Alianza Bolivariana para los Pueblos de Nuestra América), UNASUR: Dél-amerikai Nemzetek Uniója (Unión de Naciones Suramericanas), CELAC: Latin-amerikai és Karibi Államok Közössége (Comunidad de Estados Latinoamericanos y Caribeños).

6 Harriet Alexander: Donald Trump cancels first trip to Latin America 'to deal with Syria crisis', [online], 2018. 04. 10. Forrás: The Telegraph [2020. 01. 27.]

7 Adam TAYLOR: Trump makes his first presidential visit to Latin America - a region where he is very unpopular, [online], 2018. 11. 30. Forrás: The Washington Post [2020. 01. 27.]

8 Travels Abroad of the President, [online], Forrás: Office of the Historian [2020. 01. 27.]

9 Travels Abroad of the Secretary of State, [online], Forrás: Office of the Historian [2020. 01. 27.] Alexander MaIn: The Right Has Power in Latin America, but No Plan, [online], 2019. 08. Forrás: Jacobin [2020. 01. 27.] 
esetében az Észak-amerikai Szabadkereskedelmi Egyezmény (North American Free Trade Agreement - NAFTA, 1994), valamint Costa Rica, a Dominikai Köztársaság, El Salvador, Guatemala, Honduras és Nicaragua vonatkozásában a CAFTA-DR (Dominican Republic - Central America Free Trade Agreement, 2005) szabályozza, míg Chilével (2004), Kolumbiával (2012), Panamával (2012) és Peruval (2007) bilaterális szerződések vannak hatályban, amelyek mindegyikét Trump három elödje kötötte. Az „America First” kampány logikájába kevésbé illeszkedő/illeszthető szabadkereskedelmi megállapodásokról Trump számtalan alkalommal elítélően nyilatkozott, kampányidőszaka alatt legélesebben a TPP-t és a NAFTA-t kritizálva.

Az Obama által 2015-től erőteljesen támogatott TPP, azaz a Csendes-óceáni Partnerség (Trans-Pacific Partnership) létrehozása nem eredményezett volna valódi bővülést a szabadkereskedelmi partnerek számában LAC-szinten (Latin America and the Carribean - a továbbiakban: LAC), hiszen csak a már meglévő szabadkereskedelmi megállapodással rendelkező országok (Chile, Mexikó, Peru) szerepeltek a potenciális tagjelöltek között. Amennyiben aláírják, 11 másik tagországgal együtt az Egyesült Államok részévé válhatott volna a világ eddigi legnagyobb regionális szabadkereskedelmi övezetének, amely a globális szinten elöállított GDP mintegy 40\%-áért felelös, közel 28 billió $\left(28 \times 10^{12}\right)$ dollár értékben. ${ }^{10} \mathrm{~A}$ már Obama idején is rendkívül nagy vitát kiváltó kezdeményezést Trump is kampánytémává tette, élesen elutasítva a megállapodás aláíását. Végül a Kongresszus által egyébként még nem jóváhagyott megállapodástervezetből Trump hivatalban töltött első teljes munkanapján léptette ki az Egyesült Államokat, ahogy a sajtótájékoztatón elmondta: „[V]éget fogunk vetni a nevetséges kereskedelmi megállapodásoknak, melyek mindenkit eltüntettek az országunkból, vállalatokat tüntettek el az országunkból, és ezt most meg fogjuk fordítani." ${ }^{11}$ E gondolatmenet mentén kritizálta Trump a még Bill Clinton által tető alá hozott NAFTA-t is. A kezdeti időszakban még az is felmerült - legalábbis retorikai szinten -, hogy az Egyesült Államok egyszerüen kilép a megállapodásból. Végül aztán Trump első hivatali évében háromoldalú tárgyalások kezdődtek, amelyek 2018 szeptemberére hoztak sikert: USMCA (United States - Mexico - Canada Agreement, Egyesült Államok - Mexikó - Kanada Megállapodás) néven született meg, amely „modernizálta” a negyedévszázados NAFTA rendelkezéseit, elsősorban a digitális kereskedelem, valamint a tej- és az autóipar vonatkozásában. ${ }^{12}$

De nemcsak a kereskedelem, hanem a támogatáspolitika terén is elégedetlen volt Trump a megelőző időszakok döntéseivel, ennek kapcsán mindenképpen szót kell ejteni az Egyesült Államok külföldi segélyként a LAC-régióba juttatott támogatásának alakulásáról. Az 1. ábra jól szemlélteti a jelenlegi és a korábbi kormányzatok közti nagyságrendbeli különbséget, amely különösen abban az esetben szignifikáns, ha a Trump által kért költségvetési támogatás mértékét az Obama alatti időszak számaival (vagy a nyolc év átlagával) vetjük össze. Emellett szintén jelentős eltérés (egyharmad versus kétharmad) fedezhető

10 Kevin Granville: What Is TPP? Behind the Trade Deal That Died, [online], 2017. 01. 23. Forrás: The New York Times [2020. 01. 28.]

11 Peter Baker: Trump Abandons Trans-Pacific Partnership, Obama’s Signature Trade Deal, [online], 2017. 01. 23. Forrás: The New York Times [2020. 01. 27.]

12 Mark P. Sullivan: Latin America and the Caribbean: U.S. Policy Overview, [online], 2019. 11. 13. Forrás: Federation of American Scientists [2020. 01. 27.] 
fel a Trump által kért és a Kongresszus (a Képviselőház, illetve a Szenátus Előirányzatok Bizottságai) által megszavazott költségvetés között. Tette ezt a Kongresszus vélelmezhetően már csak azért is, mert a törvényhozás két házának illetékes bizottságai az évek során számtalan jelentésben jutottak arra a következtetésre, hogy az elsődleges problémát jelentő migráció kiváltó okait az adott országok célzott (pénzbeli, szakmai és politikai) támogatásával lehetséges csak fenntartható módon, hosszú távon megoldani.

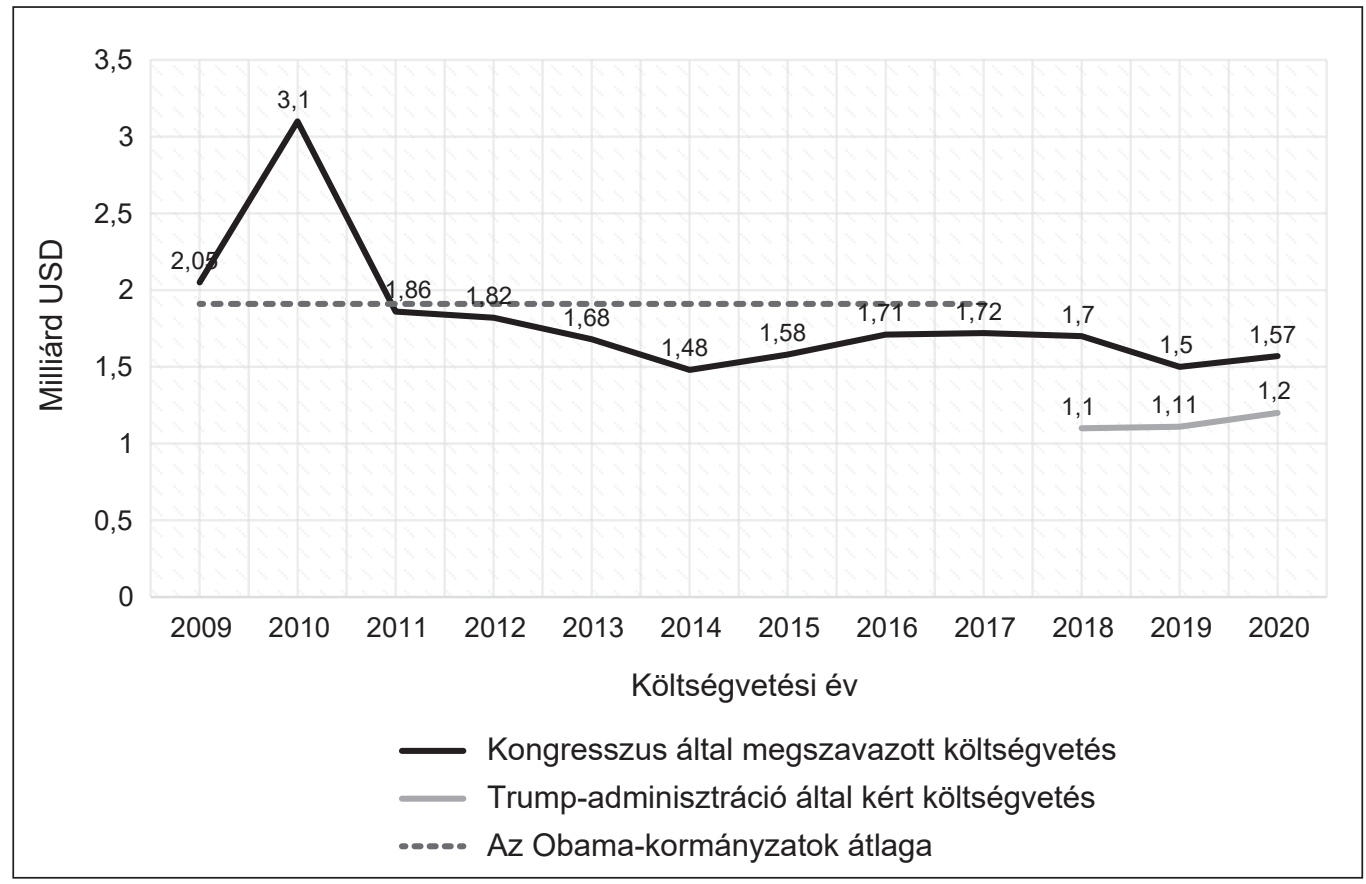

\section{1. ábra: Az Egyesült Államok által külföldi segélyekre fordított összegek alakulása a LAC-régió vonatkozásában (2009-2020 költségvetési év)}

Forrás: a szerző szerkesztése U.S. Congress Committee Reports, [online], Forrás: Congress.gov [2020. 01. 12.] alapján ${ }^{13}$

\section{Migráció: Mexikó és a „Mexikók”}

Az alcím természetesen Trump kedvenc hírcsatornája, a Fox News 2019 áprilisában elhíresült szalagcímére utal, ahol leegyszerüsítően a „mexikói problémákkal” azonosított három közép-amerikai országot, az „északi háromszög” államait, azaz Guatemalát, Hondurast és El Salvadort illeték e kifejezéssel, amiért később hivatalosan is bocsánatot kért a tévétársaság. A baki azonban rendkívül jól jellemzi az amerikai közhangulatot, amelyet Trump a kampánya kezdete óta ki is használ: a déli határ egyet jelent az illegális migrációval, a drogcsempé-

13 Az adatok forrása: az Egyesült Államok 2009-2020 közötti költségvetését szabályozó jogszabályok. 
szettel és a szervezett bünözői csoportok egyre szofisztikáltabb tevékenységével. E témában Trump talán legemblematikusabb kijelentése, hogy falat fog építtetni az ország déli határszakaszára, amelynek költségeit Mexikóval fizetteti meg. Az abszurdnak hangzó kijelentés olyan sokszor hangzott el a már beiktatott elnök szájából is, hogy mexikói kollégája, Peña Nieto lemondta 2017 elejére tervezett washingtoni útját. Bár Trump idővel felhagyott a fal ilyetén való megépítésével (a határvédelmi rendszerről részletesebben, lásd lejjebb), az ellenséges retorika azonban elmérgesítette a viszonyt a két ország között. A helyzetet tovább tetézte, hogy Trump 2017 szeptemberében felfüggesztette a 2012-ben Obama által indított DACA (Elhalasztott Intézkedés a Gyerekkorban Érkezetteknek, Deferred Action for Childhood Arrivals) programot. A gyermekként illegális bevándorlókkal az Egyesült Államokba érkezőknek átmeneti védettséget biztosító program felfüggesztése ellen több száz keresetet nyújtottak be, majd a Legfelsőbb Bíróság is vizsgálni kezdte a kérdést, de a közel 700 ezer - egy még az ezredfordulót követően benyújtott törvényjavaslat alapján „dreamer”-nek („álmodozónak”) nevezett ${ }^{14}$ - fiatal státuszával kapcsolatos döntést a grémium 2019 végéig még nem hozta meg. ${ }^{15}$

Hasonlóan alakult a helyzet a több mint két évtizedes múlttal rendelkező „Átmeneti védett státusz" (Temporary Protected Status - TPS) intézményével, amely jelenleg 10 ország - köztük négy latin-amerikai, Nicaragua (1999), Honduras (1999), El Salvador (2001) és Haiti (2010) - állampolgárai számára érhető el. ${ }^{16}$ A TPS egy diszkrecionális alapon müködő humanitárius támogatási forma, amit a Belbiztonsági Minisztérium által meghatározott országok állampolgárai kaphatnak, amelyeket fegyveres konfliktus, illetve természeti katasztrófa sújtott, vagy bármely olyan körülmény, amely limitálja az ország lehetőségeit, hogy visszafogadja állampolgárait az Egyesült Államokból. Bár a TPS-államok többsége (valamint a programban korábban szereplő három másik ország) Latin-Amerikán kívüli, a bevándorlók döntő többsége, akik mentességet kaptak a TPS-programnak hála, LACországokból származnak. Trump már kormányzása kezdetétől élesen kritizálta a programot, majd a Belbiztonsági Minisztérium 2017 szeptemberében bejelentette annak várható leállítását a négy latin-amerikai ország (illetve Nepál és Szudán) vonatkozásában. Trump végül döntést hozott a hat ország státuszának megszüntetéséről, arra hivatkozva, hogy az adott államokban helyreállt a rend, és a programra már nincs szükség. ${ }^{17} \mathrm{~A}$ határozat ellen számos beadványt nyújtottak be jogvédő csoportok, így végül 2018 októberében szövetségi bírói ítélet született, amely felfüggesztette Trump döntésének végrehajtását. A civil ellenállás és a bírósági ügyek pedig végül visszakozásra késztették a kormányzatot: a döntés bevezetésének kezdő dátumát 2021. január 4-re, illetve az eredeti döntésnek kedvező

14 A DREAM törvény(javaslato)t - ami az angol nyelvü verzió Development, Relief and Education for Alien Minors szó kezdőbetűiből tevődik össze, lényegében egy szójátékként utalva arra, hogy annak tartalma mit jelenthet a jogosultak számára - 2001. augusztus 1-jén a demokrata Dick Durbin illinois-i és a utah-i Orrin Hatch republikánus szenátor nyújtotta be, ami azóta többszöri is előkerült az évek során, de nem sikerült megfelelő támogatottságot szerezni hozzá. S.1291 - DREAM Act, [online], 2001. 08. 01. Forrás: Congress.gov [2020. 01. 27.]

15 Adam Liptak: Supreme Court Appears Ready to Let Trump End DACA Program, [online], 2019. 11. 15. Forrás: The New York Times [2020. 01. 28.]

16 Temporary Protected Status, [online], 2019. 11. 18. Forrás: U.S. Citizenship and Immigration Services [2020. 01. 28.]

17 Latin America and the Caribbean: Issues in the $115^{\text {th }}$ Congress, [online], 2019. 01. 22. Forrás: Federation of American Scientists [2020. 01.22.] 
bírói itélet esetén annak napját követő 120 napon belüli időpontra módosították. Az utolsó lezárt teljes évre, azaz 2018-ra vonatkozóan, a négy LAC-állam részéröl 392637 fó élvezett TPS-védelmet. ${ }^{18}$

Az Egyesült Államokban menedéket keresőkkel szembeni fellépés Washington regionális politikájának egyik sarokköveként nem merült ki e két program megszüntetése érdekében tett lépésekben. A Trump-kormányzat 2018-ban „zéró toleranciát” vezetett be az illegális határátlépőkkel szemben, valamint megszigorította a menedékjog megszerzésének körülményeit. Az Igazságügyi Minisztérium által bevezetett szigorított eljárásrend alapján a hatóság ezt követően a felnőttkorú illegális határátlépők ellen indított eljárás idejére mintegy 3000 gyereket választott el a szüleiktől, egészen 2018 júniusáig, amikor egy szövetségi bírói ítélet alapján be kellett szüntetni az eljárást, és egyesíteni kellett a családokat. ${ }^{19}$ Szintén további szigorításként Jeff Sessions, az igazságügyi tárca azóta leköszönt első emberének 2018. június 11-én hozott döntése alapján a latin-amerikai szervezett bűnözői csoportok (gangek), valamint a nem állami szereplők által elkövetett családon belüli erőszak áldozatai általánosságban nem felelnek meg a menekültstátusz megadásához szükséges kritériumoknak. ${ }^{20} \mathrm{~A}$ sokat vitatott döntést egy bírósági ítélet azóta megsemmisítette.

A Trump-kormányzat azonban nemcsak azon programok felszámolását tüzte ki célként, amelyek esetleg migrációt generáló tényezőként (pull faktorként) hathatnak, hanem látványos intézkedéseket tett a menekültügyi eljárások terén is. A Belbiztonsági Minisztérium által 2019. január 25-én bejelentett „Migránsvédelmi Protokoll” (Migrant Protection Protocols - MPP), népszerűbb nevén a „Maradj Mexikóban!” program lényege, hogy az Egyesült Államokba Mexikó felől szárazföldön érkező illegális vagy nem megfelelő dokumentációval rendelkező bevándorlónak az eljárás ideje alatt vissza kell mennie Mexikóba, és csak az ügyintézés időtartamára léphet be az Egyesült Államok területére.

Bár a választási kampány és Trump kezdeti hivatali időszakának hangsúlyos része volt a déli határra nehezedő migrációs nyomás, ha megnézzük az Egyesült Államok Vámés Határvédelmi Hivatala (U.S. Customs and Border Protection - USCBP) által publikált hivatalos számokat (2. ábra), akkor a havi lebontásból látszik, hogy Trump hivatalba lépésének hónapjában volt 2001 - azaz mind az ifjabb Bush, mind Obama mindkét terminusát is magában foglaló időszak - óta a legalacsonyabb a letartóztatott illegális bevándorlók száma. Ez azonban ezt követően szinte azonnal emelkedni kezdett, 2018 második felére pedig elérte és meg is haladta az Obama-adminisztráció 8 évének havi átlagát, azaz a 35 ezer föt.

18 Országonkénti lebontásban: El Salvador 251.445, Honduras 80.570, Haiti 56.114, Nicaragua 4.508. Victoria MACCHI: US Extends Protected Status End Date for Nationals of 6 Countries, [online], 2019. 11. 02. Forrás: Voice of America News [2020. 01.28.]

19 Latin America and the Caribbean: Issues in the $115^{\text {th }}$ Congress, [online], 2019. 01. 22. Forrás: Federation of American Scientists [2020. 01.22.]

20 Matter of A-B-, Respondent (Interim Decision \#3929), [online], 2018. 06. 11. Forrás: U.S. Department of Justice [2020. 01.27.] 


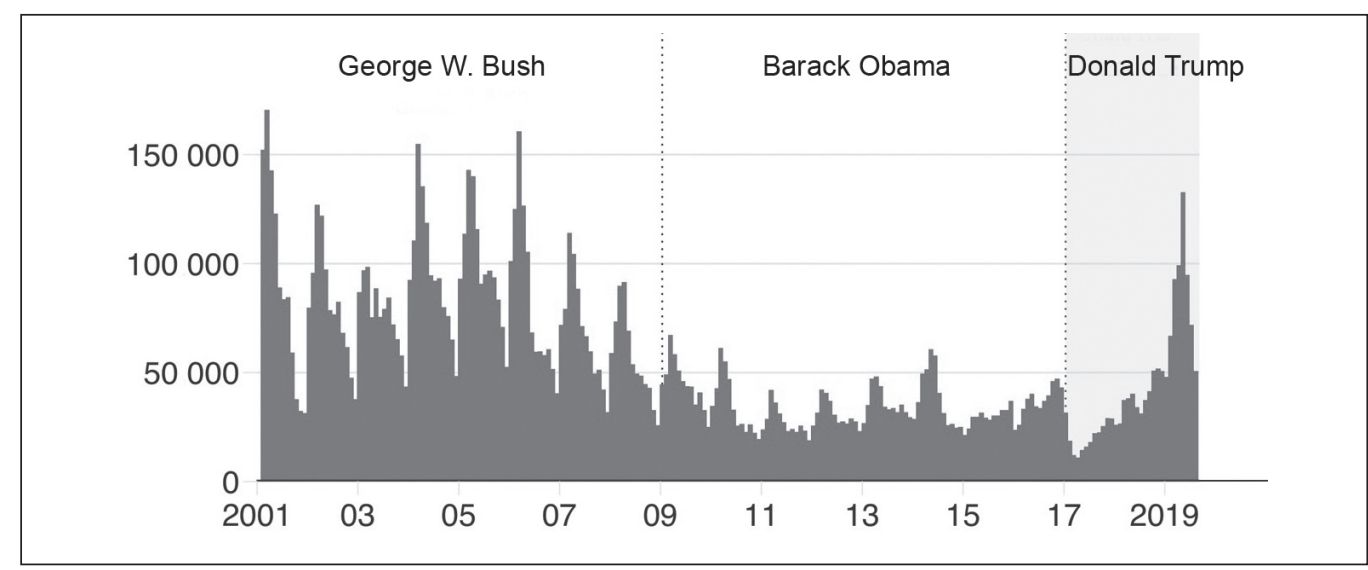

\section{2. ábra: Letartóztatott illegális határátlépök (2001. január - 2019. augusztus)}

Forrás: az Egyesült Államok Vám- és Határvédelmi Hivatala; Lucy Rodgers - Dominic BaILeY: Trump wall - all you need to know about US border in seven charts, [online], 2019. 09. 27. Forrás: BBC News

[2020. 01.28.]

A harcias washingtoni retorika, valamint a fent ismertetett intézkedések tehát nem vették el a menedékkeresők kedvét attól, hogy szerencsét próbáljanak az Egyesült Államok déli határánál. Trump elnök a USCBP által jelentett számok, valamint a határvédelmi szervekre nehezedő fokozódó nyomás miatt a korábban ígért fal megépítésére többször is megpróbált pénzt szerezni, azonban tekintettel arra, hogy a Kongresszus a fal építését nem támogatta, az elnök 2019. február 15-én nemzeti vészhelyzetet hirdetett az Egyesült Államok déli határával kapcsolatosan, annak érdekében, hogy pénzt tudjon átcsoportosítani az építkezéshez. ${ }^{21} \mathrm{Az}$ intézkedés a törvényhozás megkerülése miatt mindkét pártban nagy felháborodást váltott ki, azonban a Kongresszus kétpárti határozatát a vészhelyzet feloldásáról az elnök megvétózta, így annak végrehajtását azóta több szinten folyó bírósági eljárások próbálják megakadályozni, mindeddig vegyes eredményekkel.

A Trump által többször említett „nagy és csodálatos fal” a kezdeti elgondoláshoz képest - miszerint betonból fog készülni, és a teljes 3145 kilométeres mexikói határszakaszon felépül majd - a hónapok, majd évek során sokat változott, jelenlegi állás szerint valószínüsíthetően egy megerősített fémkerítés lesz inkább, és csak azon a szakaszon, ahol a természetes határ (folyók) hiánya ezt feltétlenül szükségessé teszi. 2017 januárja óta különböző forrásokból mintegy 9,8 milliárd dollárt tudott Trump biztosítani a fal elkészítéséhez, amelynek kivitelezési költségei 12 és 70 milliárd dollár között mozoghatnak. Az USCBP például 6,5 millió dollár/mérföld (1,6 kilométer) áron kalkulál. Összehasonlításképpen, az ifjabb Bush elnöksége alatt épült, valamivel több mint 1000 kilométeres könnyüszerkezetü kerítés mintegy 7 milliárd dollárba került. „Trump falából” 2019 harmadik negyedévének kezdetéig mindössze egy 20 kilométeres szakasz készült el, valamint egy nagyjából kétszer ekkora szakasz előkészületi munkái zajlanak Texasban. Emellett egy 90 kilométeres

21 Proclamation 9844 - Declaring a National Emergency Concerning the Southern Border of the United States, [online], 2019. 02. 20. Forrás: Federal Register [2020. 01. 27.] 
kerítéscsere és egy 15 kilométeres másodlagos kerítés épült meg. 2020 végére a tervek szerint a megépült új „fal-” szakasz eléri a 720 kilométert. ${ }^{22}$

Mintegy fél évvel a „Maradj Mexikóban!” irányelv hatályba lépését követően, július 15-én a Belbiztonsági Minisztérium további szigorítást vezetett be, amely alapján azok a személyek, akik utazásuk során harmadik biztonságos országban nem kértek menekültstátuszt, ilyen kérvényt az Egyesült Államokban sem nyújthatnak be. ${ }^{23} \mathrm{Az}$ intézkedés ellen emberi jogi szervezetek bírósághoz fordultak, amelynek következtében a döntés végrehajtását felfüggesztették, majd május elején egy ellentétes bírói döntés alapján mégis elkezdték alkalmazni. ${ }^{24} \mathrm{Az}$ intézkedés okozta tömegek kezelésére azonban Mexikó nem tudott felkészülni: a határmenti településeken várakozó tízezrek - akiket egyfajta „pszichológiai hadviselés” keretében a szándékosan csökkentett számú napi ügyintézések miatt még tovább várakoztatnak az amerikai hatóságok - lakhatási körülményei, szociális és egészségügyi ellátása nem megoldott, a sérelmükre elkövetett büncselekmények száma pedig szintén kritikus szintet ért el több városban, a médiában pedig számos rémtörténet kering a menekültügyi eljárás megváltozása miatt kialakult állapotokról és egyéni tragédiákról. ${ }^{25}$

$\mathrm{Az}$ amerikai kormányzat idővel természetesen felismerte, hogy annak érdekében, hogy valódi változást és „fenntartható bevándorláspolitikát” tudjon megvalósítani - kiegészítendő a „saját háza táján” igencsak vegyes képet mutató döntéseket -, együtt kell működnie a határ másik oldalán állókkal. Nem meglepő módon ez a fajta „együttműködés" is beleillik a Trumptól megszokott egyedi külpolitikai irányvonalba. E tanulmánynak mindazonáltal nem célja a két szomszédos állam egymásnak ellentmondó bejelentéseinek, Trump számtalan, olykor sértö, máskor a menekülteket démonizáló Twitter-üzeneteinek, valamint gazdasági szankciók (extra védővámok) bevezetésének lehetőségéről szóló burkolt fenyegetéseinek részletes elemzése. ${ }^{26}$ Annyi azonban bizonyos, hogy mindkét fél elkötelezett munkájának és aktív megoldáskeresésének hála, a 2019. június 7-én aláírt Egyesült Államok-Mexikó Közös Nyilatkozatban megfogalmazott „példátlan lépések”, mint a megerősített mexikói határőrizet a mexikói Nemzeti Gárda bevonásával, valamint a hatékonyabb együttműködés ${ }^{27}$ meghozta hatását, és sikerült csökkenést elérni az illegális határátlépések számában. Feltétlenül megjegyzendö, hogy bár nagy nyomás nehezedett a mexikói vezetésre, és szinte megszakítás nélkül folytak a különböző szintű tárgyalások a felek között, Washingtonnak nem sikerült rávennie Andrés Manuel López Obrador (népszerübb nevén AMLO) mexikói elnököt, hogy olyan dokumentumot írjon alá, amely harmadik biztonságos országnak nyilvánítja Mexikót. ${ }^{28}$

22 Rodgers-Bailey: i. $m$.

23 Migrant Protection Protocols, [online], 2019. 01. 24. Forrás: U.S. Department of Homeland Security [2020. 01. 28.]

24 Miriam Jordan - Zolan Kanno-Youngs: Trumpss Latest Attempt to Bar Asylum Seekers Is Blocked After a Day of Dueling Rulings, [online], 2019. 07. 24. Forrás: The New York Times [2020. 01. 28.]

25 Micah Luxen - Jessica Lussenhop - Rajini Vaidyanathan: Is there a crisis on the US-Mexico border?, [online], 2019. 07. 11. Forrás: BBC News [2020. 01. 28.]

Elliot Spagat: Migrants live in fear at Mexico-US border as violence flares, [online], 2019. 11. 07. Forrás: AP News [2020. 01.28.]

26 Michael D. Shear - Maggie Haberman: No Secret Immigration Deal Exists With U.S., Mexico’s Foreign Minister Says, [online], 2019. 06. 10. Forrás: The New York Times [2020.01. 28.]

27 U.S.-Mexico Joint Declaration, [online], 2019. 06. 07. Forrás: U.S. Department of State [2020. 01. 29.]

28 Daina Beth Solomon: Mexico says no to safe third-country asylum discussion with U.S., [online], 2019. 07. 22. Forrás: Reuters [2020. 01.29.] 
Mexikó déli szomszédjának helyzete azonban más. Miután a Trump-adminisztráció kellő diplomáciai nyomás alá helyezte a hivatalából távozó Jimmy Morales guatemalai elnököt, 2019. július 26-án aláírták azt a dokumentumot, amely biztonságos harmadikország-kategóriába sorolta a közép-amerikai országot. Az első hallásra akár még komikusnak is ható megállapodás mind az Egyesült Államokban, mind Guatemalában széles körü tiltakozást váltott ki, a guatemalai legfelsőbb bíróság végül átmenetileg felfüggesztette a jogszabály hatályba lépését. A kérdés a 2019-es elnökválasztási kampány egyik hangsúlyos témája is lett, a választáson győztes, 2020. január 14-én hivatalba lépő Alejandro Giammattei pedig programjában tett ígéretet arra, hogy „újra fogja tárgyalni” a megállapodást, mert az „nem fair” Guatemalára nézve. ${ }^{29}$

2019, az alfejezet szempontjából talán utolsó jelentősebb eseménye a november 4-én, nyolc halálos áldozatot követelö, észak-mexikói mormon családok elleni támadást követő bejelentés volt, amely szerint Trump már hónapok óta tárgyal és vizsgáltatja annak lehetőségét, hogy a mexikói bünbandákat - akiket a támadás elkövetésével is gyanúsítanak - az Egyesült Államok terrorszervezetként ismerje el. A Twitteren bejelentett fejleményeket azonban nem erősítették meg mexikói részről, az ország külügyminisztere, Marcelo Ebrard nyilatkozatában feleslegesnek nevezte a felvetést. ${ }^{30}$

\section{Régi-új nemezisek: Kuba, Venezuela és Nicaragua}

Bár a három ország merőben eltérő helyzetben van, és különböző lehetőségekkel rendelkezik, az erőteljesen baloldali és autoriter berendezkedés mégis egy csoporttá kovácsolja őket. Ezt nem utolsósorban az a washingtoni retorika is erősíti, amely már korábban is szerette az olyan jól kommunikálható, könnyen kezelhető címkéket, mint az ifjabb Bush-időszak „Gonosz tengelye”, amely jelen esetben a három ország vonatkozásában a „Zsarnokság trojkája" formájában jelent meg John Bolton, Trump egykori, sorrendben negyedik nemzetbiztonsági tanácsadójának 2018. november 2-án elmondott beszédében. ${ }^{31}$

\section{Kuba}

Az 1960-as évek eleje óta az Egyesült Államok részéről egyre erősödő gazdasági embargóval sújtott Kuba irányába a mandátuma vége felé gesztusokat tevő Obama-kormányzat lépései már az elnökválasztási kampányban negatívumként kerültek napirendre Trump oldaláról, ami nagy valószínűséggel hozzá is járult a floridai elektori szavazatok megszerzéséhez 2016-ban. A demokrata elnökség végével a békülékenyebb hangvétel annak ellenére teljesen megszakadt a szigetországgal, hogy Raúl Castro 2018-2019 során szinte minden

29 Adriana Beltrán: Guatemala Is No Safe Third Country - Why the Asylum Deal Is a Mistake, [online], 2019. 09. 25. Forrás: Foreign Affairs [2020. 01. 29.]

Trevor Sutton: Trump pushes failed Latin America policy now reflected in Guatemala, [online], 2019. 09. 05. Forrás: The Hill [2020. 01. 29.]

30 Liam Stack - Kirk Semple: Trump Says U.S. Will Designate Drug Cartels in Mexico as Terrorist Groups, [online], 2019. 11. 28. Forrás: The New York Times [2020. 01. 29.]

31 Remarks by National Security Advisor Ambassador John R. Bolton on the Administration's Policies in Latin America, [online], 2018. 11. 02. Forrás: The White House [2020. 01. 01.] 
tisztségéről lemondott a Kubai Kommunista Párt első titkári posztjának kivételével (ezzel nem mellesleg teljesítette az 1996-os Helms-Burton-törvény egyik fontos kitételét), valamint 2019. április 10-én hatályba lépett az előző év júliusában a Nemzetgyúlés által elfogadott, majd a februári népszavazás során is megerősített új kubai alkotmány, amely számos releváns változást hozott (többek között olyan témákban, mint a magántulajdon elismerése, a külföldi befektetések engedélyezése és az ártatlanság vélelme). Trump szigorításait első körben - 2017 júniusától - ${ }^{32}$ az Obama előtti megszorításokhoz való visszatérésként lehet értelmezni. Ezek elsősorban az Egyesült Államok állampolgárainak utazási lehetőségeire, illetve a Kubába utalható pénz mennyiségére vonatkoztak, majd ezt követte a gazdasági szankciók kiterjesztése különböző kubai politikai és katonai körök tagjaira, rokonaikra, valamint üzleti érdekeltségeikre.

Annak érdekében, hogy ne csak az Egyesült Államok állampolgárait, de egyéb egyéni vagy üzleti befektetőket is el tudjanak riasztani a szigetországban történő beruházástól, Mike Pompeo amerikai külügyminiszter 2019. április 17-én bejelentette, hogy Trump elnök nem hosszabbította meg a már említett Helms-Burton-törvény - hivatalos nevén a „Kubai szabadság és demokratikus szolidaritás törvény” (Cuban Liberty and Democratic Solidarity (Libertad) Act) - III. cikkének felfüggesztését, amit a jogszabály 1996-os hatályba lépésétől kezdve minden félév elteltével megtett az épp hivatalban lévő elnök. Ezzel a jogi aktussal - azaz a III. cikk felfüggesztésének elmaradásával - megnyílt a lehetőség, hogy az Egyesült Államokban keresetet nyújthassanak be azok a korábbi tulajdonosok, akiknek a kubai állam a forradalmat követően államosította ingó vagy ingatlan vagyonát. A perelhetőség ugyancsak kiterjed harmadik országok állampolgáraira és az ott bejegyzett cégekre is. Az intézkedés, amelynek hatására akár 200 ezer per is megindulhat, a nemzetközi közösség több szereplöje szerint is sérti a nemzetközi jogot, számos ország pedig - köztük Kanada és az Európai Unió ${ }^{33}$ - jogszabályokat hozott érdekeltségeik és állampolgáraik védelmében. ${ }^{34}$

A karibi szigetországot érintő szankciók utolsó hullámát az időközben egyre jobban eszkalálódó venezuelai helyzetre adott washingtoni reakció jegyében vezették be annak érdekében, hogy megzavarják, illetve jobb esetben megszüntessék a Kuba és Venezuela közti szimbiózist.

32 Szintén az időszak fontos, bár valószínűleg nem szándékos és előre tervezett történése, hogy 2017 szeptemberében egy a havannai nagykövetség dolgozóit érintő titokzatos megbetegedéshullám miatt Washington mintegy kétharmadával csökkentette a diplomáciai testület állományát, jelentős fennakadásokat okozva a helyi ügyintézésben. Latin America and the Caribbean: Issues in the 115th Congress, [online], 2019. 01. 22. Forrás: Federation of American Scientists [2020. 01.22.]

33 Kanada és az EU közös nyilatkozatban ítélte el és nevezte "sajnálatosnak" az Egyesült Államok lépését. Joint Statement by EU High Representative/Vice President Federica Mogherini, Minister of Foreign Affairs of Canada Chrystia Freeland and EU Commissioner for Trade Cecilia Malmström on the decision of the United States to further activate Title III of the Helms Burton (Libertad) Act, [online], 2019. 04. 17. Forrás: Government of Canada [2020. 01. 02.]

34 Jason Rotstein: The Legacy of the Libertad Act: Defeating Title III Claims and Protecting International Comity, [online], 2019. 11. Forrás: Harvard International Law Journal [2020. 01. 02.] 


\section{Venezuela}

A Hugo Chávez 2013-as halálát követően hatalomra kerülő Nicolás Maduro, illetve az általa vezetett kormányzat antidemokratikus és számos jogszabályt sértő tevékenysége elleni fellépésként már Obama ideje alatt megszületett az első jogszabály, a 2014-es Venezuelai emberi jogokat és civil társadalmat védö törvény (Venezuela Defense of Human Rights and Civil Society Act of 2014). Trump hivatalba lépésekor azonban már teljesen más volt a helyzet Venezuelában: a szinte folyamatosan súlyosbodó belpolitikai válság egyre inkább összeforrt az országot sújtó gazdasági válsággal, a hatalmat minden áron megtartani akaró Maduro és hívei (különös tekintettel a collectivóknak nevezett felfegyverzett civil erőkre), valamint a korábbiakhoz képest egységesebb ellenzék és támogatóik között hónapról hónapra fokozódó feszültség a békésebb demonstrációk mellett halálos áldozatokat is követelö összetüzésekké fajult. Ezt a helyzetet - elsősorban politikai és nemzetközi síkon - tovább bonyolította, hogy a Nemzetgyülés 2019. január 5-én Juan Guaidó ellenzéki képviselőt választotta meg elnökévé. Miután Maduro január 10-én az előző évi, sokak által vitatott elnökválasztás eredményeként megkezdte második terminusát, a Nemzetgyülés azt illegitimnek minősítette, január 23-án pedig a Venezuelai Alkotmány 233. cikkelyére hivatkozva Guaidó átmeneti elnöknek kiáltotta ki magát. Az Egyesült Államok és Venezuela kapcsolatát pedig mi sem illusztrálja érzékletesebben, mint hogy Mike Pence alelnök ezt megelözően, január 22-én egy közvetlen hangvételü, ámbátor erőteljes üzenetben tudatta Venezuela lakosságával, hogy az Egyesült Államok támogatja ellenállásukat a diktátorként említett Maduróval szemben, egyben hitet tett Juan Guaidó mellett. ${ }^{35}$ Az eset után kevesebb mint egy héttel a Fehér Ház sajtótájékoztatójára érkező John Bolton akkori nemzetbiztonsági tanácsadó jegyzetfüzetének véletlenül (?) kifelé forduló lapján egy kézzel írt „5000 fős alakulat Kolumbiába” feljegyzés volt olvasható, amelyet később természetesen senki nem kommentált. ${ }^{36}$

Az Egyesült Államok tehát már a kezdetektől emblematikus szereplője a venezuelai eseményeknek, és minden egyes nagyobb fordulópontnál érzékeltette, hogy nemcsak megfigyelője, de alakítója is kíván lenni az eseményeknek. A két említett eset és a számtalan Twitteren és sajtótájékoztatókon elmondott üzenet mellett a szankciók egyre szofisztikáltabb rendszere alakult ki annak érdekében, hogy térdre kényszerítse a Maduro-rezsimet. A büntető intézkedések hat kategóriába sorolhatók aszerint, hogy a szankcionált tevékenység milyen módon támogatja a Maduro-kormányzat hatalmon maradását, valamint az illegális forrásokból származó pénz külföldre juttatását:

1. terrorizmus támogatása miatt kivetett szankciók;

2. kábítószer-kereskedelem miatt kivetett szankciók;

3. antidemokratikus és/vagy emberi jogokat sértő tevékenység, illetve korrupció miatt kivetett szankciók;

35 Jeff Mason: 'Hola, I'm Mike Pence': U.S. VP delivers message of support to Venezuelans, [online], 2019. 01. 22. Forrás: Reuters [2020. 01.02.]

36 Margaret TAlev: Hint to Maduro? '5,000 Troops to Colombia,' Reads Bolton Notepad, [online], 2019. 01. 29. Forrás: Bloomberg [2020. 01.02.] 
4. egyéb szektorokat érintő szankciók (aranykitermelés [Minerven, állami aranybánya-vállalat], állami vállalatok [PdVSA olajvállalat, ${ }^{37}$ Aerogaviota légitársaság], vegyesvállalatok [Evrofinance Mosnarbank], illetve a venezuelai katonai kémelhárítás, a DGCIM);

5. egyéb pénzügyi szankciók (venezuelai adósság vásárlása, digitális valutával - elsősorban Petróval - való kereskedelem),

6. a Maduro-kormány és segítőivel szemben kiszabott szankciók (állampolgárságra való tekintet nélkül). ${ }^{38}$

A nyilvánosan hozzáférhető információk alapján, 2019 végén a pénzügyminisztérium 132 személy ellen hozott intézkedést a fenti hat kategória valamelyikében, míg a külügyminisztérium több száz érintett vízumát vonta vissza, illetve tette őket beutazási tiltólistára. ${ }^{39} \mathrm{~A}$ lista azonban nemcsak a szankcionálás eszköze, hanem a dezintegrációé is: azzal, hogy valaki lemond hivataláról vagy megtagadja a szolgálatot (dezertál), és ezt az Egyesült Államokkal együttmüködve (valószínüsíthetően információk átadásával, esetleges egyéb más kollaborációval) teszi, azzal le tud kerülni a listáról, ahogy ez történt Manuel Cristopher Figuera egykori vezérőrnagy, a venezuelai hírszerzés, a hírhedt SEBIN volt parancsnoka esetében, ${ }^{40}$ aki az egyik fö konspirátora volt a 2019. április 30-ai sikertelen katonai puccskísérletnek. ${ }^{41}$

Megjegyzendő, hogy bár a venezuelai helyzet jelenlegi állását Washingtonban senki sem támogatja, a szankciók mértéke, a szankcionáltak köre, valamint az intézkedések által másodlagosan okozott károk, illetve az arányosság, valamint a katonai beavatkozás lehetősége számos vitát generált és generál az amerikai szakmai és tudományos szervezetek mellett kormányzati körökben és a törvényhozásban egyaránt. ${ }^{42}$

37 Az USA persze továbbra is Venezuela első számú exportpartnere.

38 Clare Ribando Seelke: Venezuela: Overview of U.S. Sanctions, [online], 2019. 10. 16. Forrás: Federation of American Scientists [2020. 01.03.]

39 A listán szerepel többek között Maduro, felesége, Cecilia Flores, gyermekük, Nicolás Maduro Guerra, az alelnök, Delcy Rodriguez, Diosdado Cabello, a Szocialista Párt elnöke, nyolc bíró a Legfelsőbb Bíróság soraiból, a venezuelai hadsereg, a nemzetőrség, valamint a rendőrség vezetői; négy állam kormányzója, a Venezuelai Központi Bank igazgatója, a külügyminiszter, Jorge Arreaza, a volt alelnök, jelenlegi ipari és nemzeti termelésügyi miniszter, Tareck el Aissami.

40 A listáról való lekerülés ténye épp ezért legalábbis felveti az Egyesült Államok valamilyen szintű részvételét az akcióban. Ribando SeELKe: $i . m$.

41 2019. április 30-án, Juan Guaidó a Caracas melletti La Carlota légierőbázisról videóüzenetben kérte támogatóit, hogy álljanak mellé az általa a Maduro-rezsim elleni felkelés utolsó fázisaként említett akcióhoz. A „Szabadság-hadművelet” (Operación Libertad) nevet viselő katonai puccskísérletben a videó tanúsága szerint mintegy két tucat katona arcát vállalva, nyíltan támogatta Guaidót, azonban az elsősorban alacsonyabb rendfokozatú állomány mellé nem csatlakoztak nagyobb számban további egyenruhás támogatók, így Iván Duque kolumbiai elnök és Mike Pompeo amerikai külügyminiszter gyors szóbeli támogatása ellenére sem tudott sikert elérni. A venezuelai haderő nem demoralizálódott, a hadsereg nem állt át Guaidó mögé. A kísérlet komolyabb veszteségek, illetve sérülések nélkül ért véget. Az eset körüli legkomolyabb fejlemény Leopoldo López ellenzéki vezető felbukkanása volt, akit kiszabadítottak házi őrizetéből, így részt tudott venni az akcióban. Lásd: Venezuela opposition leader Juan Guaido calls for military uprising against Nicolas Maduro, [online], 2019. 04. 30. Forrás: CBS News [2020. 01. 12.]

42 Jeff Faux: Why Are Leading Democrats Supporting Trump on Venezuela?, [online], 2019. 05. 23. Forrás: The Nation [2020. 01. 02.]; The Presidential Candidates on Venezuela, [online], 2019. 07. 30. Forrás: Council on Foreign Relations [2020.01.02.] 


\section{Nicaragua}

Kubához hasonlóan a trojka harmadik országa, Nicaragua és annak baloldali elnöke, Daniel Ortega sem új szereplöje az Egyesült Âllamok regionális problémakörének: az 1970es években a sandinista mozgalom élén még fegyverekkel ragadta magához a hatalmat, amelyet 1984-ben alapvetően szabad választásokat nyerve törvényesített. Majd több mint másfél évtizedes ellenzéki szerep után a 2006-os választáson újra sikerült megszereznie a hatalmat. A 2017-es, kérdéses tisztaságú helyhatósági választásokat követően egyre erősödött az elégedetlenség Ortega rendszerével szemben, ahol korábban a gazdasági és szociális intézkedések hatása képes volt kiegyensúlyozni az antidemokratikus intézkedéseket. Azonban 2018 áprilisától - amikor az elnök számos szociális intézkedés visszavonását jelentette be a fizetésképtelenség elkerülése érdekében - ez a törékeny egyensúly megbomlott, és az utcára vonuló egyetemistáknak és a többi elégedetlennek már nem volt elég, hogy Ortega visszavonta a döntést és reformokat ígért. ${ }^{43} \mathrm{~A}$ számos ellenzéki politikus és újságíró bebörtönzésével, olykor megkínzásukkal járó, valamint a demonstrációkra egyre durvábban reagáló központi hatalom több mint 320 halálos áldozatot és több száz sérültet követelő fellépése miatt számos állam és nemzetközi szervezet, köztük az Amerikai Államok Szervezete is elítélte az Ortega-kormányzatot, és felszólította az elnököt a lemondásra. 2018 júliusában az Amerika-közi Emberi Jogi Bizottság (Inter-American Commission on Human Rights - IACHR) emberiesség elleni büntett elkövetése gyanújának minősítette a biztonsági erők fellépését. Ezt követően, 2018 decemberében a Kongresszus elfogadta a „Nicaraguai emberi jogi és antikorrupciós törvényt" (Nicaragua Human Rights and Anticorruption Act of 2018) ${ }^{44}$, amely arra kötelezi az Egyesült Államokat nemzetközi hitelező intézményekben és szervezetekben képviselőket, hogy Nicaragua hitelfelvétele ellen járjanak el, kivéve amikor „alapvető emberi szükségletek ellátására” vagy a „demokrácia erősítéséhez szükséges támogatásra" van szüksége a közép-amerikai államnak. A jogszabály emellett felhatalmazza az elnököt, hogy az emberi jogi büncselekmények elkövetői és a jelentős korrupciós tevékenységben érintett személyek ellen szankciókat vezessen be. 2019 végén az elnök mellett felesége, az alelnöki tisztséget betöltő Rosario Murillo, valamint fiuk, Laureano Ortega is a szankcionált személyek listájára került. Utóbbi azzal az indoklással, hogy ő a 74 éves elnök kijelölt utódja, és számos korrupciós ügylet is a nevéhez köthetö. ${ }^{45}$

A „terror mocskos háromszöge” („sordid triangle of terror”) ${ }^{46}$ - a másik kifejezés, ahogy Bolton emlegette a három államot - tehát számos kihívást állított az Egyesült Államok elé. A washingtoni vezetés és nem utolsósorban konkrétan maga Trump elnök az elmúlt

43 A The Economist Intelligence Unit mértékadó elemzése, a Demokrácia Index 2018-as évet összefoglaló kiadásában Nicaragua - rontva korábbi besorolásához - csatlakozott a régió korábbi két autoriter állama, Kuba és Venezuela mellé. Democracy Index 2018: Me too? - Political participation, protest and democracy, [online], 2019 Forrás: The Economist Intelligence Unit [2020. 01. 04.]

44 Nicaragua Human Rights and Anticorruption Act of 2018, [online], 2018. 07. 18. Forrás: Congress.gov [2020. 01. 04.]

45 Latin America and the Caribbean: Issues in the 115th Congress, [online], 2019. 01. 22. Forrás: Federation of American Scientists [2020. 01.22.]

46 Matthew Waterman: Bolton is reviving old rhetoric and old policies on Latin America, [online], 2019. 04. 28. Forrás: IDS News [2020. 01. 15.] 
három évben kiemelten kezelte a kubai, venezuelai és nicaraguai kérdést. Azonban szignifikáns változást egyetlen esetben sem sikerült elérni annak ellenére, hogy a három ország nemcsak a spanyolajkú szavazók megnyerése szempontjából rendelkezik rendkívüli fontossággal, hanem mert mindhárom ország egyre erősödő orosz és kínai hídföállást jelent az Egyesült Államok „hátsó udvarában” politikai, gazdasági és nem utolsósorban katonai vonatkozásban. Ez utóbbit támasztja alá az a tény is, hogy a Képviselőház külön feladatot szabott a Védelmi Hírszerzö Ügynökség (Defence Intelligence Agency - DIA) részére, hogy készítsen elemzést az orosz katonai tevékenységről és együttműködésről e három országban. ${ }^{47}$

\section{További területek: kábítószer, régi-új kihívók}

Egy Latin-Amerikával, illetve az Egyesült Államok Latin-Amerika-politikájával foglalkozó elemzés sem lehet teljes a kábítószer-kereskedelem említése nélkül. Különösen, mivel az Egyesült Államokba érkező kokain előállításáért felelős Kolumbia 2017-ben rekordmagas termelést ért el, ${ }^{48}$ ez a mennyiség pedig, kiegészülve a Mexikóból érkező heroin-, metamfetamin- és fentanilszállítmányokkal a 2010-es évek végére már nagymértékben növelte a kábítószerhasználattal összefüggő halálozások számát az Egyesült Államokban. ${ }^{49}$

A droghelyzet, valamint az ahhoz kapcsolódó szervezett bünözés eszkalálódásának megakadályozására az Egyesült Államok már több kormányzattal korábban is számos program és kétoldalú együttműködés beindításával próbált fellépni: a Plan Colombia (2000) (különösen annak Plan Patriota programja), majd az azt felváltó Peace Colombia is nagy részben ezt a célt tüzte ki maga elé Kolumbia vonatkozásában, ${ }^{50}$ ahogy a mexikói fókusszal rendelkező Mérida Kezdeményezés (Mérida Initiative - MI, 2007) ${ }^{51}$, a Közép-amerikai Regionális Biztonsági Kezdeményezés (Central America Regional Security Initiative - CARSI, 2008) és a Karib-medencei Biztonsági Kezdeményezés (Caribbean Basin Security Initiative - CBSI, 2009) is. E megállapodások Trump hivatalba kerülését követően is fennmaradtak, azonban a programok hangsúlyai kifejezetten a kábítószer-kereskedelem és az abban részt vevő szervezett bünözői csoportok elleni fellépésre helyeződtek, amely az Egyesült Államok felé irányuló migráció egyik fő kiváltó oka El Salvadorban, Hondurasban és Guatemala egyes részein. ${ }^{52}$ Ennek folyományaképpen az Igazságügyminisztérium listája alapján végül Trump személyes döntése értelmében az egyik külön is kiemelt célpont a Mara Salvatrucha

47 Cuba: U.S. Policy in the 116th Congress, [online], Forrás: Federation of American Scientists [2020. 01. 15.]

48 New Annual Data Released by White House Drug Policy Office Shows Record High Cocaine Cultivation and Production in Colombia, [online], 2018. 06. 28. Forrás: The White House [2020. 01. 05.]

49 Sullivan: $i . m$.

50 Adam Isacson: "Peace Colombia": What's New About It?, [online], 2016. 02. 15. Forrás: Washington Office on Latin America [2020. 01. 05.]

51 Suzanne Gamвод: The U.S. and Mexico have waged war on drug cartels for decades. They've fallen short, [online], 2019. 11. 05. Forrás: NBC News [2020. 01. 05.]

52 Latin America and the Caribbean: U.S. Policy Overview, [online], 2020. 01. 11. Forrás: Federation of American Scientists [2020.01.15.] 
(MS-13) $)^{53}$ nevü nemzetközi szervezett bünözői csoport lett. A Mérida Kezdeményezésen és a CARSI-n keresztüli regionális együttmüködésnek köszönhetően az MS-13 több ezer tagja ellen sikerült vádat emelni az Egyesült Államokban. Az MI kézzelfogható sikere ellenére Andrés Manuel López Obrador mexikói elnök már választási kampányában is kritizálta a programot, hivatalba lépését követően pedig több alkalommal is kijelentette, hogy Mexikó „nem akar több Mérida programot, nem akar több felfegyverzett helikoptert, fejlesztési támogatást akar", így az MI jövője még kérdéses. ${ }^{54}$

Fontos megjegyezni azonban, hogy több régióbeli ország legfelsőbb vezetése (politikai és katonai egyaránt) is erős kötődéssel, olykor meghatározó szereppel rendelkezik a nemzetközi kábítószer-kereskedelemben. Juan Orlando Hernández hondurasi elnökkel szemben az Egyesült Államok által az elnök testvére ellen 2019 októberében indított eljárás során kerültek elő bizonyítékok; Tareck el Aissami ellen még venezuelai alelnökként merültek fel bizonyítékok, többek között kábítószer-kereskedelem támogatásában való részvételre, ${ }^{55}$ majd 2019 elején a New York-i szövetségi bíróság emelt vádat ellene, hogy aztán július végén már a Bevándorlási és Vámügyi Hivatal Top10 körözött személy listáján szerepeljen. ${ }^{56}$

Végezetül pedig, bár utalásként már szerepeltek korábban, de külön is szót kell ejteni Washington regionális politikájának két szereplőjéről, amelyek talán a vártnál valamelyest hangsúlytalanabbul jelennek meg: Oroszországról és Kínáról. Az orosz térnyerés ténye - bár nem jelent meg különösebb hangsúllyal - nem lehetett nagy újdonság a Trumpkormányzat számára, hiszen első kézből származó információkkal rendelkeztek John F. Kelly nyugállományú vezérezredestől, az USA Déli Parancsnokságának (USSOUTHCOM) egykori parancsnokától, aki a Trump-adminisztráció első belbiztonsági minisztere, majd ezt követően második kabinetfönöke volt. Kelly már 2015-ös szenátusi meghallgatásán beszélt Moszkva térségbeli szerepnövekedéséről: „Oroszország 2008 óta fokozott jelenlét fenntartására törekszik Latin-Amerikában propaganda, fegyverek és katonai felszerelések értékesítése, kábítószer-ellenes megállapodások és kereskedelem révén. Putyin elnök alatt azonban egyértelmű visszatérést tapasztaltunk a hidegháború taktikájához. Globális stratégiájának részeként Oroszország erőkivetítő képességét használja annak érdekében, hogy

53 A különös kegyetlenségéről ismert Mara Salvatrucha egy eredetileg az 1970-1980-as években, Los Angelesben, a salvadori bevándorlók védelme érdekében létrejött szervezet. A kezdeti időszakot követően azonban egy kisebb-nagyobb csoportok („,likas”) laza hálózatából álló, jelenleg az Egyesült Államok mellett elsősorban Mexikóban és Közép-Amerikában aktív, klasszikus értelemben vett szervezett bűnözői csoporttá alakult, amely bevételeit védelmi pénzek szedéséből, ember-, fegyver-, illetve kábítószer-csempészetéből és ezekkel való kereskedésből, valamint autólopásokból, bérgyilkosságok elkövetéséből és prostitúcióból szerzi. A Trump 2019-es évértékelő beszédében (State of the Union) egyes számú közellenséggé és a menekültellenes politika emblémájává tett MS-13 éves bevétele a becslések szerint összességében a több száz millió dolláros nagyságrendet is eléri. Lásd: MS13 in the Americas - How the World’s Most Notorious Gang Defies Logic, Resists Destruction, [online], 2018. 02. 16. Forrás: InSight Crime - Center for Latin American \& Latino Studies [2020. 01. 12.]; Dara LinD: MS-13, explained - President Trump has turned the Salvadoran-American street gang into public enemy No. 1., [online], 2019. 02. 05. Forrás: VOX Media [2020. 01. 12.]

54 Diego OrÉ: Mexico wants U.S. backing for development plan to stem Central American migration, [online], 2019. 05. 20. Forrás: Reuters [2020. 01. 06.]

55 US accuses Venezuelan vice-president of role in global drug trafficking, [online], 2017. 02. 14. Forrás: The Guardian [2020. 01. 06.]

56 ICE: Former Venezuelan VP among 10 most wanted fugitives, [online], 2019. 07. 31. Forrás: AP News [2020. 01. 06.] 
rombolja az Egyesült Államok vezető szerepét, és folyamatos kihívásokat állítson befolyásával szemben a nyugati féltekén." ${ }^{57}$

Kína kapcsán néhány adat szintén elgondolkodtató. A LAC-régió és az ázsiai ország kereskedelmi mérlege az ezredforduló 10 milliárd dolláros szintjéről 2018-ra 307,4 milliárd dollárra nőt annak ellenére, hogy szinte valamennyi érintett országban lelassult a gazdaság. 2019-re, kizárólag a 12 dél-amerikai államot tekintve Kína lett az első számú exportpartner, míg a teljes latin-amerikai és Karibi-térség számára a második (az Egyesült Államok után). Ennél azonban talán még jelentősebb a hitelkihelyezések és befektetések változása. 2005-ben Peking mindössze egyetlen országnak nyújtott 30 millió dolláros összeget egy hitel keretében, 2019-ben 16 országba mintegy 136,886 milliárd dollár érkezett 89 hitelszerződés alapján. ${ }^{58}$ Ezzel párhuzamosan, a 2013-ban „Egy Övezet, Egy Út” (One Belt One Road - OBOR, 2013) néven Hszi Csi-ping kínai elnök által indított grandiózus geostratégiai-gazdasági projektben eredetileg fel sem merült a LAC-térség. Az időközben „Övezet és Út Kezdeményezés” (Belt and Road Initiative - BRI, 2016) névre váltó projekt 2019-es második fórumán azonban már 19 LAC-ország szerepelt az aláírók között. ${ }^{59} \mathrm{~A}$ helyzetet legjobban talán Rick Scott, floridai republikánus szenátor CNBC-n megjelent véleménycikke érzékelti, amelyet a térség számos országába tett, 2019. májusi körútja után írt: „Ha most nem nézünk szembe ezzel a [kínai - a szerző] fenyegetéssel, később így is, úgy is meg kell tennünk. De ha várunk, sokkal gyengébb pozícióban leszünk, mint most. Kína pedig továbbra is át fog gyalogolni rajtunk." ${ }^{60}$

A felismerés ellenére a nyilvánosan elérhető dokumentumok tanúsága szerint szakpolitikai szinten nincs kiemelt szerepe Oroszországnak és Kínának sem. Rex Tillerson külügyminiszter számos latin-amerikai országot érintő, 2018-as körútja és sajtónyilatkozatai, valamint a Kongresszus két házának bizottsági tevékenységei azonban azt bizonyítják, hogy Washington természetesen tisztában van a két nagyhatalom regionális szerepnövekedésének jelentőségével. ${ }^{61}$ Úgy tünik, hogy a probléma inkább az, hogy a Trump-kormányzat nem találja a jelenség ellenszerét. Az elmúlt nagyjából két évtized során, a „pink tide” időszakának előnyös politikai átrendeződését és egyéb kedvező világgazdasági folyamatokat kihasználó Moszkva és Peking sikeresen erősítette meg regionális pozícióit: mind orosz, mind kínai részről jelentős hitelkihelyezés volt megfigyelhető az említett időszakban, ezzel párhuzamosan számos óriásberuházás indult meg elsősorban az infrastruktúra és az energetika területén, valamint katonai együttmüködések (fegyvereladások, közös hadgyakorlatok, katonai létesítmények telepítése) is beindultak a felek között. Washington pedig - ideértve Trumpot és két elődjét - egyelőre úgy tünik, hogy adós marad egy versenyképes,

57 Posture statement of General John F. Kelly, United States Marine Corps, Commander, United States Southern Command Before the 114th Congress Senate Armed Services Committee 12 March 2015., [online], 2015. 03. 12. Forrás: Senate.gov [2020. 01. 06.]

58 Kevin P. Gallagher - Margaret Myers: China-Latin America Finance Database, [online], 2020. Forrás: Inter-American Dialogue [2020.01. 12.]

59 The Belt and Road Initiative, [online], 2020. Forrás: Hong Kong Trade Development Council [2020. 01. 12.]

${ }^{60}$ Rick Sсотт: China's growing influence in Latin America is a threat to our way of life, [online], 2019. 06. 11. Forrás: CNBC [2020. 01. 14.]

${ }_{61}$ Tillerson Warns against China, Russia Engagement in Latin America, [online], 2018. 02. 01. Forrás: Voice of America [2020.01.07.] 
a régió történelmi érzékenységére figyelmet fordító és nem utolsósorban fenntartható ajánlat megfogalmazásával.

\section{Záró gondolatok. Az állóvíz felkavarása? Trump-doktrína?}

Azzal, hogy Donald Trump 2016-ban a megnyerő „Tegyük Úra Naggyá Amerikát” és „Amerika az első” szlogenekkel kezdte meg választási kampányát, és MAGA ${ }^{62}$ feliratú sapkában azóta is többször látni hivatalos eseményeken és sajtótájékoztatókon, egy rendkívül leegyszerüsített módon, de doktrínát hirdetett. Az Egyesült Államok mindenek feletti elsődlegessége pedig szinte minden döntésében tetten érhetö. A korábbi fejezetekben Trump kampányígéreteit és e „baseballsapka-doktrínának” a latin-amerikai megjelenését összegeztem az ígéret és tettek dichotómiájában, ennek során külön kiemelve az adminisztráció azon döntéseit (elnöki, illetve miniszteri szinten), amelyeket a végrehajtói hatalmi ág mellett működő igazságszolgáltatás vagy a törvényhozás függesztett fel vagy semmisített meg.

Úgy gondolom, hogy Trump talán minden korábbi elnöknél karakteresebb terveit - amelyek, bár sokszor inkább csak ötletként tűnnek fel - a tőle telhetö legkövetkezetesebb módon próbálja megvalósítani. A menekültkérdés rendezése, még ha egyelőre a fal fizikális megépítése nélkül is, de a ,jogszabályi fal” megerösítésével nemcsak, hogy megkezdődött, de eredményeket is fel tud mutatni. Az persze más kérdés, hogy Trump doktrínájába az már nem illik bele, hogy legalább bilaterális - vagy regionális szinten kölcsönösen előnyös szituációk alakulhassanak ki, hiszen ezt nem is ígérte, és a választói sem ezt várják el tőle. A közép-amerikai államokat eddig valamelyest segítő, és a problémák gyökerét is megcélzó programok helyett a jogszabályi változásoknak köszönhetően immár leginkább csak a probléma tüneteinek kezelésével foglalkozik Washington. Ezzel nemcsak azt érte el az elnök, hogy az eddig sem minden esetben túl erős kapcsolatrendszere tovább gyengült, de az esélyeket is csökkentette a probléma valódi megoldására. Véleményem szerint, bár rövid távon egyes mutatók jelezhetnek az Egyesült Âllamokra nézve pozitív változást, példának okáért az illegális bevándorlók számának csökkenésében, köszönhetően a Mexikóra helyezett nyomásnak és az élénkebb ellenőrzésnek, azonban a „nagy kibocsátó" országokat támogató programok leállítása tovább fogja eszkalálni a helyzetet. Így tovább fog erősödni az elvándorlást erősítő tényezők hatása, ezért ez a rendszer hosszú távon nem tartható fenn. Az olyan lépések pedig, mint például Guatemala biztonságos harmadik országgá nyilvánítása, a világszinten is rendkívül kedvezőtlen bünügyi statisztikák - és a józan ész - ellenére, akár az USA nemzetközi megítélésének is árthatnak.

Szintén nem tesz jót az ország kapcsolatrendszerének, ha bizonyos döntések érzékeny területeket bolygatnak meg. Amikor egyes vezetők több száz éves történelmi eseményeket hánytorgatnak fel, és bocsánatkérésre szólítanak fel - ahogy tette ezt AMLO is VI. Fülöp spanyol királynak és Ferenc pápának írt levelében ${ }^{63}$-, akkor oda kell figyelni még a látszatra is. Például nem lehet olyan személyt kulcspozícióba helyezni, akinek egyes nemzetek számára már a puszta jelenléte is fájó sebeket tép fel. Elliott Abrams venezuelai különmegbízottá

62 MAGA: Make America Great Again.

63 Mexico demands apology from Spain and the Vatican over conquest, [online], 2019. 03. 26. Forrás: BBC News [2020. 01. 08.] 
történő kinevezése, Abrams hidegháború alatti közép-amerikai szereplésének, és különösen az Irán-kontra-ügy kapcsán tett Kongresszus előtti hamis vallomástétele miatti büntetésének tudatában, semmiképp sem nevezhető megfontolt politikai döntésnek. Problémák teljesen új körét nyitja meg egy egyébként is feszült és érzékeny kérdés kapcsán, teljesen feleslegesen. ${ }^{64}$ Sőt, egy megújulásra törekvő, hosszú távon is fenntartható tervekkel rendelkező elnökség akár a történelmi megbékélésen is munkálkodhatna annak érdekében, hogy megváltozzon az Egyesült Államok nem túl fényes régiós megítélése. Ennek hiányát azonban jogosan nem lehet felhánytorgatni egy republikánus kormányzatnak, amikor az a korábbi demokrata elnökség nyolc éve alatt is csak kisebb mértékben ment végbe.

Ez tehát nem a legnagyobb elszalasztott lehetőség. Az Egyesült Államok és a déli szubkontinens óriása, Brazília kapcsán azonban már lehet hiányérzetünk. Hiába az ideológiaigondolkodásbeli közösség, hiába a megszólalásig hasonló temperamentum és kommunikáció - nem véletlen, hogy Bolsonaro beceneve „Trópusi Trump” -, az sem hozott túl sok konkrét eredményt, hogy Brazília elnöke 2019 márciusában Washingtonba látogatott. Bár eddig csak egy év átfedés volt a két elnöki terminus között, nem történt számottevő elörelépés a jelenleg szinte természetes szövetségesnek mondható Brazília és az Egyesült Államok kapcsolatában sem gazdasági, sem politikai téren.

Mindez talán annak tudható be, hogy a Tillerson által 2018-ban ismertetett külpolitikai stratégia kerete mellett nem tünik úgy, hogy a Trump-kormányzatnak konkrét elképzelései lennének a LAC-térséggel kapcsolatban, leszámítva a fenti alfejezetekben említett, számára kedvezőtlen folyamatok és jelenségek (migráció, kábítószer-kereskedelem, szocialista kormányok) elleni fellépést. Valószínüleg javára vált volna a Trump-adminisztráció külügyi vezetőinek, ha nem mindig a belföldi politikai haszonszerzésre koncentrálnak, akár az elsősorban floridai spanyolajkú szavazatok megszerzése kapcsán, akár a demokrata elnökjelölt-aspiránsok lejáratása („szocialistázása”) kapcsán, hanem a regionális együttmüködések egy új korszakának kialakításán munkálkodtak volna.

Összességében azonban, ha mérleget kívánnánk vonni Donald Trump elnöki időszakának Latin-Amerika-politikájáról, a fent hangsúlyozott problémák ellenére a mérleg egyik serpenyője sem maradna üresen. Az elnök sajátos retorikája és egyedi megközelítési módja, sokszor átgondolatlannak tünő kijelentései, döntései vita nélkül jelentős változásokat hoztak a régió életébe, egyes esetekben pedig, ha nem is a megszokott (elfogadott) módon, de elérték, hogy a felek kimozduljanak a nyugvópontról, és valós, számszerűsíthető változásokat tudjanak megvalósítani.

\section{FELHASZNÁLT IRODALOM}

Alexander, Harriet: Donald Trump cancels first trip to Latin America 'to deal with Syria crisis', [online], 2018. 04. 10. Forrás: The Telegraph [2020. 01. 27.]

BAKER, Peter: Trump Abandons Trans-Pacific Partnership, Obama’s Signature Trade Deal, [online], 2017. 01. 23. Forrás: The New York Times [2020. 01. 27.]

64 Anne Gearan: Neocon and Iran-contra figure Elliott Abrams in line for State Department job, [online], 2017. 02. 09. Forrás: The Washington Post [2020. 01. 08.] 
Beltrán, Adriana: Guatemala Is No Safe Third Country - Why the Asylum Deal Is a Mistake, [online], 2019. 09. 25. Forrás: Foreign Affairs [2020. 01. 29.]

Cuba: U.S. Policy in the $116^{\text {th }}$ Congress, [online]. Forrás: Federation of American Scientists [2020. 01. 15.]

Democracy Index 2018: Me too? - Political participation, protest and democracy, [online], 2019. Forrás: The Economist Intelligence Unit [2020. 01. 04.]

Faux, Jeff: Why Are Leading Democrats Supporting Trump on Venezuela?, [online], 2019. 05. 23. Forrás: The Nation [2020. 01. 02.]

Gallagher, Kevin P. - Myers, Margaret: China-Latin America Finance Database, [online], 2020. Forrás: Inter-American Dialogue [2020. 01. 12.]

GamboA, Suzanne: The U.S. and Mexico have waged war on drug cartels for decades. They've fallen short., [online], 2019. 11. 05. Forrás: NBC News [2020. 01. 05.]

GeAran, Anne: Neocon and Iran-contra figure Elliott Abrams in line for State Department job, [online], 2017. 02. 09. Forrás: The Washington Post [2020. 01. 08.]

Granville, Kevin: What Is TPP? Behind the Trade Deal That Died, [online], 2017. 01. 23. Forrás: The New York Times [2020. 01.28.]

ICE: Former Venezuelan VP among 10 most wanted fugitives, [online], 2019. 07. 31. Forrás: AP News [2020. 01. 06.]

IsAcson, Adam: "Peace Colombia": What's New About It?, [online], 2016. 02. 15. Forrás: Washington Office on Latin America [2020. 01. 05.]

Joint Statement by EU High Representative/Vice President Federica Mogherini, Minister of Foreign Affairs of Canada Chrystia Freeland and EU Commissioner for Trade Cecilia Malmström on the decision of the United States to further activate Title III of the Helms Burton (Libertad) Act, [online], 2019. 04. 17. Forrás: Government of Canada [2020. 01. 02.]

Joint Strategic Plan FY 2018-2022, [online], 2018. 02. Forrás: U.S. Department of State [2020. 01. 28.]

Jordan, Miriam - Kanno-Youngs, Zolan: Trump's Latest Attempt to Bar Asylum Seekers Is Blocked After a Day of Dueling Rulings, [online], 2019. 07. 24. Forrás: The New York Times [2020. 01. 28.]

Latin America and the Caribbean: Issues in the $115^{\text {th }}$ Congress, [online], 2019. 01. 22. Forrás: Federation of American Scientists [2020. 01.22.]

Lind, Dara: MS-13, explained - President Trump has turned the Salvadoran-American street gang into public enemy No. 1., [online], 2019. 02. 05. Forrás: VOX Media [2020. 01. 12.]

LipTAK, Adam: Supreme Court Appears Ready to Let Trump End DACA Program, [online], 2019. 11. 12. Forrás: The New York Times [2020. 01. 28.]

Luxen, Micah - Lussenhop, Jessica - Vaidyanathan, Rajini: Is there a crisis on the US-Mexico border?, [online], 2019. 07. 11. Forrás: BBC News [2020. 01. 28.]

MACCHI, Victoria: US Extends Protected Status End Date for Nationals of 6 Countries, [online], 2019. 11. 02. Forrás: Voice of America News [2020. 01.28.]

Main, Alexander: The Right Has Power in Latin America, but No Plan, [online], 2019. 08. Forrás: Jacobin [2020. 01.27.]

Mason, Jeff: 'Hola, I’m Mike Pence': U.S. VP delivers message of support to Venezuelans, [online], 2019. 01. 22. Forrás: Reuters [2020. 01. 02.]

Matter of A-B-, Respondent (Interim Decision \#3929), [online], 2018. 06. 11. Forrás: U.S. Department of Justice [2020. 01.27.]

Mexico demands apology from Spain and the Vatican over conquest, [online], 2019. 03. 26. Forrás: BBC News [2020. 01. 08.]

Migrant Protection Protocols, [online], 2019. 01. 24. Forrás: U.S. Department of Homeland Security [2020. 01. 28.] MS13 in the Americas - How the World's Most Notorious Gang Defies Logic, Resists Destruction, [online], 2018. 02. 16. Forrás: InSight Crime - Center for Latin American \& Latino Studies [2020. 01. 12.]

New Annual Data Released by White House Drug Policy Office Shows Record High Cocaine Cultivation and Production in Colombia, [online], 2018. 06. 28. Forrás: The White House [2020. 01. 05.]

Nicaragua Human Rights and Anticorruption Act of 2018, [online], 2018. 07. 18. Forrás: Congress.gov [2020. 01. 04.]

ORÉ, Diego: Mexico wants U.S. backing for development plan to stem Central American migration, [online], 2019. 05. 20. Forrás: Reuters [2020. 01. 06.] 
Posture statement of General John F. Kelly, United States Marine Corps, Commander, United States Southern Command Before the 114th Congress Senate Armed Services Committee 12 March 2015., [online], 2015. 03. 12. Forrás: Senate.gov [2020. 01. 06.]

Proclamation 9844 - Declaring a National Emergency Concerning the Southern Border of the United States, [online], 2019. 02. 20. Forrás: Federal Register [2020. 01. 27.]

Remarks by National Security Advisor Ambassador John R. Bolton on the Administration's Policies in Latin America, [online], 2018. 11. 02. Forrás: The White House [2020. 01. 01.]

Ribando Seelke, Clare: Venezuela: Overview of U.S. Sanctions, [online], 2019. 10. 16. Forrás: Federation of American Scientists [2020. 01. 03.]

Rodgers, Lucy - BAILEY, Dominic: Trump wall - all you need to know about US border in seven charts, [online], 2019. 09. 27. Forrás: BBC News [2020. 01. 28.]

Rotstein, Jason: The Legacy of the Libertad Act: Defeating Title III Claims and Protecting International Comity, [online], 2019. 11. Forrás: Harvard International Law Journal [2020. 01. 02.]

S.1291 - DREAM Act, [online], 2001. 08. 01. Forrás: Congress.gov [2020. 01. 27.]

Sсотт, Rick: China’s growing influence in Latin America is a threat to our way of life, [online], 2019. 06. 11. Forrás: CNBC [2020. 01. 14.]

Shear, Michael D. - Haberman, Maggie: No Secret Immigration Deal Exists With U.S., Mexico's Foreign Minister Says, [online], 2019. 06. 10. Forrás: The New York Times [2020. 01. 28.]

Solomon, Daina Beth: Mexico says no to safe third-country asylum discussion with U.S., [online], 2019. 07. 22. Forrás: Reuters [2020. 01.29.]

SpAGAT, Elliot: Migrants live in fear at Mexico-US border as violence flares, [online], 2019. 11. 07. Forrás: AP News [2020. 01.28.]

Stack, Liam - Semple, Kirk: Trump Says U.S. Will Designate Drug Cartels in Mexico as Terrorist Groups, [online], 2019. 11. 28. Forrás: The New York Times [2020. 01. 29.]

Sullivan, Mark P.: Latin America and the Caribbean: U.S. Policy Overview, [online], 2019. 11. 13. Forrás: Federation of American Scientists [2020. 01. 27.]

SutTon, Trevor: Trump pushes failed Latin America policy now reflected in Guatemala, [online], 2019. 09. 05. Forrás: The Hill [2020. 01. 29.]

TALEv, Margaret: Hint to Maduro? ‘5,000 Troops to Colombia', Reads Bolton Notepad, [online], 2019. 01. 29. Forrás: Bloomberg [2020. 01. 02.]

TAYLOR, Adam: Trump makes his first presidential visit to Latin America - a region where he is very unpopular, [online], 2018. 11. 30. Forrás: The Washington Post [2020. 01. 27.]

Temporary Protected Status, [online], 2019. 11. 18. Forrás: U.S. Citizenship and Immigration Services [2020. 01. 28.]

The Belt and Road Initiative, [online], 2020. Forrás: Hong Kong Trade Development Council [2020. 01. 12.]

The Presidential Candidates on Venezuela, [online], 2019. 07. 30. Forrás: Council on Foreign Relations [2020. 01. 02.]

Tillerson Warns against China, Russia Engagement in Latin America, [online], 2018. 02. 01. Forrás: Voice of America [2020. 01.07.]

Travels Abroad of the President, [online], Forrás: Office of the Historian [2020. 01. 27.]

Travels Abroad of the Secretary of State, [online], Forrás: Office of the Historian [2020. 01. 27.]

U.S.-Mexico Joint Declaration, [online], 2019. 06. 07. Forrás: U.S. Department of State [2020. 01. 29.]

US accuses Venezuelan vice-president of role in global drug trafficking, [online], 2017. 02. 14. Forrás: The Guardian [2020. 01.06.]

Venezuela opposition leader Juan Guaido calls for military uprising against Nicolas Maduro, [online], 2019. 04. 30. Forrás: CBS News [2020. 01. 12.]

WATERMAN, Matthew: Bolton is reviving old rhetoric and old policies on Latin America, [online], 2019. 04. 28. Forrás: IDS News [2020. 01. 15.] 